NOTA

\title{
First Record of Loricariichthys edentatus (Siluriformes: Loricariidae) in the Paraná River
}

\author{
Primer registro de Loricariichthys edentatus (Siluriformes: \\ Loricariidae) en el río Paraná
}

Guillermo E. Terán ${ }^{1 *}$, Gastón Aguilera', Wilson S. Serra², Federico J. Ruiz Díaz, J. Marcos Mirande ${ }^{1}$

1 Fundación Miguel Lillo - UEL CONICET. Miguel Lillo 251, (4000) S. M. de Tucumán, Argentina.

2 Sección Ictiología, Dpto. de Zoología, Museo Nacional de Historia Natural, Montevideo, Uruguay.

3 Instituto de Ictiología del Nordeste, Facultad de Ciencias Veterinarias, Universidad Nacional del Noreste, UNNE. Sargento Cabral 2139, (3400) Corrientes, Argentina.

*guilloteran@gmail.com

\begin{abstract}
Recent expeditions to northeastern Argentina in the Paraná River revealed the presence of the armored catfish Loricariichthys edentatus Reis \& Pereira 2000, which represents the first record of this species to that basin.
\end{abstract}

Keywords - Corrientes province, distribution, endemism, range extension, La Plata River basin.

\section{RESUMEN}

Campañas realizadas al noreste de Argentina en el río Paraná revelaron la presencia de la vieja del agua Loricariichthys edentatus Reis \& Pereira 2000, que representa el primer registro de esta especie para esa cuenca.

Palabras clave - Provincia de Corrientes, distribución, endemismo, extensión de rango, cuenca del Río de la Plata.

\footnotetext{
Ref. bibliográfica: Terán, G. E.; Aguilera, G.; Serra, W. S.; Ruiz Díaz, F. J.; Mirande, J. M. 2019. “First Record of Loricariichthys edentatus (Siluriformes: Loricariidae) in the Paraná River". Acta zoológica lilloana 63 (1): 58-63. Fundación Miguel Lillo, Tucumán, Argentina. D.O.I.: https://doi.org/10.30550/j.azl/2019.63.1/4 > Recibido: 22/04/19 - Aceptado: 13/05/19 > URL de la revista: http://actazoologica.lillo.org.ar

Algunos derechos reservados. Esta obra está bajo una Licencia Creative Commons Atribución - No Comercial - Sin Obra Derivada 4.0 Internacional.
} 


\section{INTRODUCTION}

Loricariidae is one of the most diverse families within the order Siluriformes, with 988 valid species in about 70 genera (Fricke, Eschmeyer, Fong, 2019). Among members of this family, Loricariichthys Bleeker, 1862, is a diverse genus widespread in South America, being distributed in most major cis-Andean freshwater drainages up to the North of Buenos Aires (Reis \& Pereira, 2000).

According to Rapp Py-Daniel (1997), the species of Loricariichthys share the following derived features: (1) third infrapharyngobranchial with a triangular lateral flange; (2) ventral shelf of the antero- and posterohyal tall, deflected posteriorly so that it nearly forms a $180^{\circ}$ angle with the main bodies of the bones; (3) ventral processes of the Weberian complex not ossified. Also, Reis \& Pereira (2000) proposed two additional characters: (1) upper lip completely fused to the premaxillary region medially, never having a free margin with barbel-like fringes along the transverse, medial portion; the fringes, when present, are restricted to the outer, more lateral portion of the lip and (2) the lower lip of immature males and females with two thick, cushion-like structures, which are covered with small papillae and have irregular fringes along the posterior edge.

Currently, Loricariichthys is composed of 20 valid species (Fricke, Eschmeyer, Van der Laan, 2019). Six species of the genus have been recorded from Argentina (Mirande and Koerber 2015): Loricariichthys anus (Valenciennes 1836), L. edentatus Reis \& Pereira 2000, L. labialis (Boulenger 1895), L. melanocheilus Reis \& Pereira 2000, L. platymetopon Isbrücker \& Nijssen 1979, and L. rostratus Reis \& Pereira 2000. From these, Loricariichthys anus, L. labialis, L. patymetopon, and L. rostratus are known to occur in the Paraná River.

Recent expeditions to the Paraná River in Corrientes, Argentina, revealed a distinct species in this basin. The aim of this contribution is to report the occurrence of Loricariichthys edentatus in the Paraná River basin for the first time.

\section{METHODS}

Morphometric measurements were taken using calipers to nearest $0.1 \mathrm{~mm}$ following Reis \& Pereira (2000) and are expressed as percent of standard length (SL) and head length (HL). Comparative material is listed in Appendix I.

Institutional abbreviations: CI-FML: Colección Ictiológica Fundación Miguel Lillo, San Miguel de Tucumán; ZVC-P: Fish Collection of Facultad de Ciencias, Universidad de la República, Montevideo, Uruguay. 


\section{RESULTS \\ Loricariichthys edentatus Reis \& Pereira 2000 \\ Fig. 1, Table 1 \\ Material examined.- CI-FML 7593, 2, 167.3 and 178.6 mm SL. Argentina,} Corrientes, Ituzaingó, Paraná River at 27³4.822’ S; 56²41.081’ W. December 2018. Coll.: Terán, Aguilera, Ruiz Díaz \& Bugeau.

Identification.- The analyzed specimens presents the following characters: (1) absence of premaxillary teeth, (2) caudal peduncle very depressed but deepening before the caudal fin, (3) a wide rostral border (11.0 and 11.8\% HL) and (4) pointed snout in dorsal view. These characters diagnose Loricariichthys edentatus from its congeners (Reis \& Pereira, 2000). Morphometric measurements of L. edentatus (Fig. 1) from Paraná River are presented in Table 1.

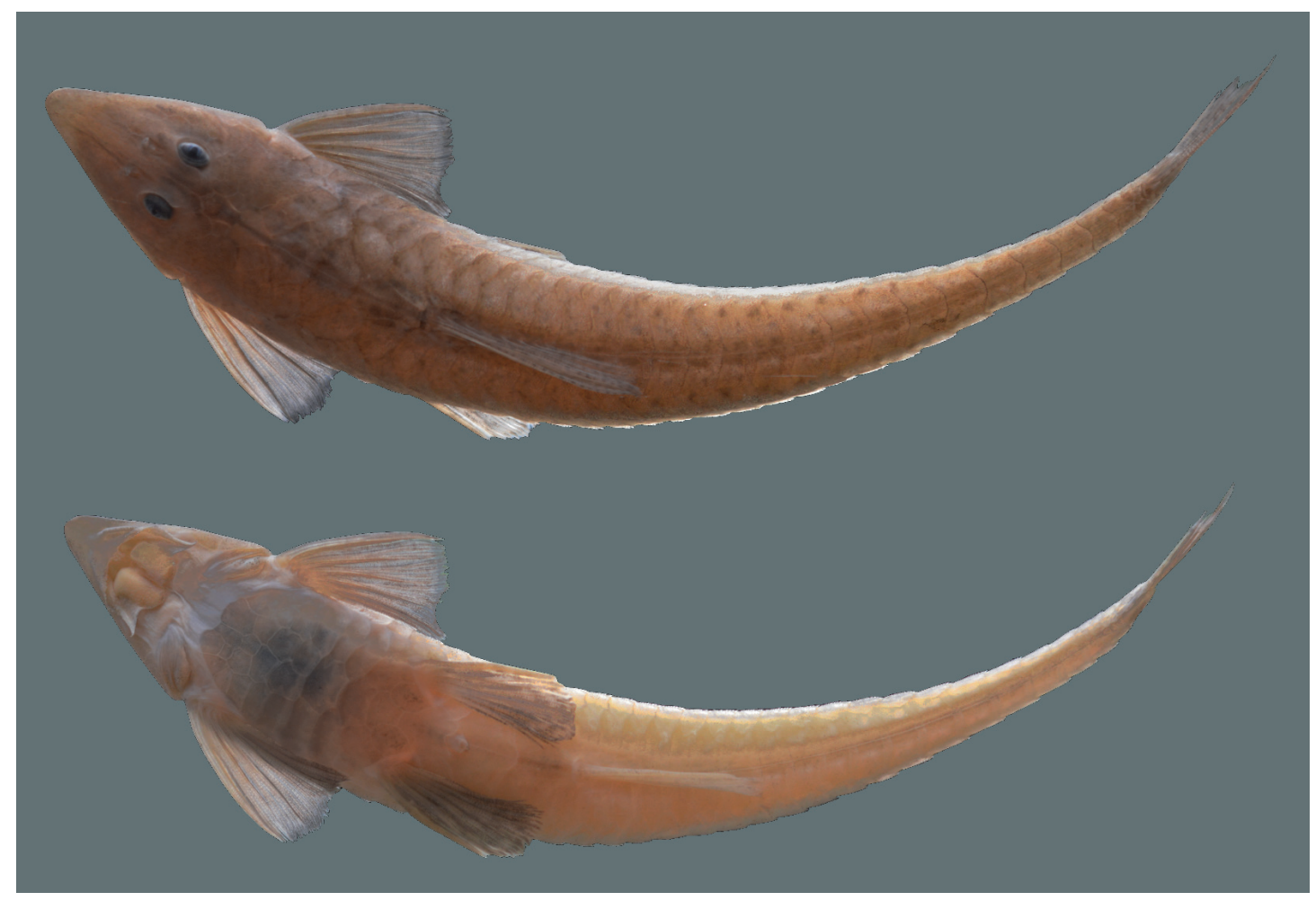

Figure 1. Loricariichthys edentatus from Paraná River. 178.6 mm Standard Length. Dorsal and ventral view (mirrored). 
Table 1. Morphometry of two specimens of Loricariichthys edentatus from Paraná River.

\begin{tabular}{|l|l|l|}
\hline & \multicolumn{2}{|c|}{ specimens } \\
\hline Morphometric measurements & 1 & 2 \\
\hline Standard length (mm) & 167.3 & 178.6 \\
\hline 1. Predorsal length & 35.7 & 36.6 \\
\hline 2. Dorsal-fin spine length & 18.6 & 18.8 \\
\hline 3. Anal-fin spine length & 13.2 & 13.7 \\
\hline 4. Pectoral-fin spine length & 14.9 & 15.0 \\
\hline 5. Ventral-fin spine length & 11.6 & 12.2 \\
\hline 6. Upper caudal ray length & 13.9 & 14.7 \\
\hline 7. Lower caudal ray length & 10.5 & 10.5 \\
\hline 8. Head length & 22.8 & 22.8 \\
\hline 9. Thoracic length & 16.5 & 15.3 \\
\hline 10. Abdominal length & 17.4 & 16.7 \\
\hline 11. Cleithral width & 15.7 & 15.0 \\
\hline 12. Body depth & 9.8 & 9.4 \\
\hline 13. Depth of caudal peduncle & 1.7 & 1.8 \\
\hline 14. Postanal length & 49.9 & 50.8 \\
\hline 15. Snout length & 51.3 & 52.5 \\
\hline 16. Head depth & 35.5 & 37.1 \\
\hline 17. Interorbital width & 15.0 & 15.0 \\
\hline 18. Eye diameter & 13.9 & 13.2 \\
\hline 19. Orbital diameter & 19.5 & 18.6 \\
\hline 20. Rostral border length & 11.0 & 11.8 \\
\hline
\end{tabular}

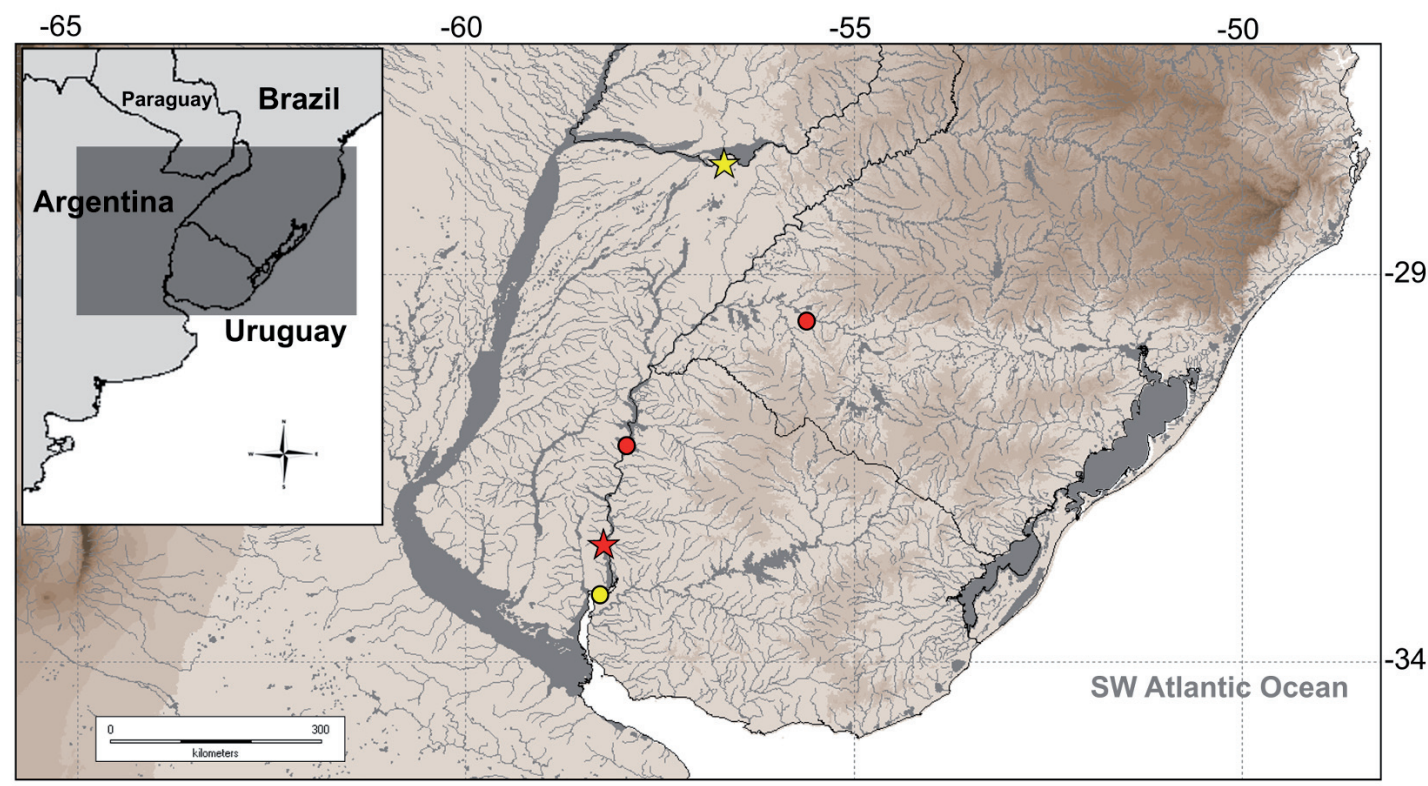

Figure 2. Geographic distribution of Loricariichthys edentatus. Previous records in red (Reis \& Pereira, 2000 and Bertaco et al., 2016; star indicates type locality), new records in yellow (star indicates locality in Paraná River). 


\section{DISCUSSION}

This new record expands the known distribution of Loricariichthys edentatus to the Paraná River basin (Fig. 2). Additionally, this is the first record for the province of Corrientes.

The known distribution range of Loricariichtys edentatus includes the Uruguay River basin, in Argentina, Brazil, and Uruguay. According to López et al. (2002) Loricariichtys edentatus was the only fish endemic to the "Lower Uruguay River Ecoregion». This new record expands the known distribution to the Paraná River basin, contradicting the hypothesis of López et al. (2002).

\section{ACKNOWLEDGMENTS}

We thank Baltazar Bugeau for field support and Perdro Sánchez for logistical assistance. This manuscript was carefully revised by Stefan Koerber. Fundación Miguel Lillo and UEL-CONICET for permanent support. This manuscript was beneficed by comments of Roberto Reis and Mercedes Azpelicueta. We thank Mariano Ordano for the editorial assistance.

\section{FUNDING}

This work was supported by Fundación Miguel Lillo and UEL CONICET.

\section{PARTICIPATION}

All authors contributed equally to the idealization, analysis, and writing.

\section{CONFLICTS OF INTEREST}

Authors declare no conflict of interest.

\section{LITERATURE CITED}

Bertaco, V. A., Ferrer, J., Carvalho, F. R. \& Malabarba, L. R. (2016). Inventory of the freshwater fishes from a densely collected area in South America - a case study of the current knowledge of Neotropical fish diversity. Zootaxa, 4138: 401-440.

Fricke, R., Eschmeyer, W. N. \& Van der Laan, R. (2019). Catalog of Fishes: Genera, Species, References. Electronic version accessed 16/IV/2019. (http://researcharchive.calacademy.org/research/ichthyology/catalog/fishcatmain.asp). 
Fricke, R., Eschmeyer, W. N. \& Fong, J. D. (2019). Catalog of Fishes: Species by Family / Subfamily. Electronic version accessed 16/IV/2019. (http://researcharchive.calacademy.org/research/ichthyology/catalog/SpeciesByFamily.asp).

López, H. L., Morgan, C. C. \& Montenegro, M. J. (2002). Ichthyological ecoregions of Argentina. Probiota, FCNyM, UNLP, Serie Documentos, 1: 1-68.

Mirande, J. M., \& Koerber, S. (2015). Checklist of the freshwater fishes of Argentina (CLOFFAR). Ichthyological Contributions of PecesCriollos 36: 1-68.

Py-Daniel, L. R. (1997). Phylogeny of the Neotropical armored catfishes of the subfamily Loricariinae (Siluriformes: Loricariidae). PhD thesis, University of Arizona $280 \mathrm{p}$.

Reis, R. E., \& Pereira, E. H. (2000). Three new species of the loricariid catfish genus Loricariichthys (Teleostei: Siluriformes) from southern South America. Copeia, 2000: 1029-1047.

\section{COMPARATIVE MATERIAL}

Loricariichthys edentatus: ZVC-P 5663, 1, 113.6 mm SL, Uruguay, Río Negro

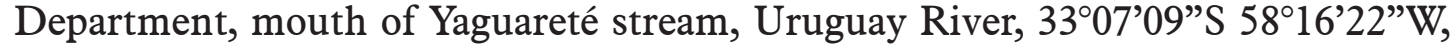
12/XII/2003, Coll.: F. Teixeira de Mello, A. D’Anatro \& M. Loureiro. ZVC-P 12970, 9, 72.7-143.8 mm SL, Uruguay, Uruguay River, exact locality unknown, 2004. 